Tomasz Jedynak

Department of Risk Management and Insurance

Cracow University of Economics ${ }^{1}$

\title{
The shape of the pension scheme in Poland in the light of the conventional multi-pillar typologies
}

\section{Summary}

In recent years, a number of modifications that have a significant impact on the shape of the pension system in Poland are introduced and discussed (e.g. OFE [Open Pension Funds] reform, implementation of the PPK [Employee Capital Plans], introduction of civil pensions, etc.). The result of these changes is that the traditional, three-pillar way of presenting the shape of this system does not reflect its essence any more. On the basis of the typologies of multi-pillar pension systems proposed in the literature, the study propose a new concept for presenting the shape of the general pension system in Poland. It consists of four levels of pension security, distinguished by the criterion of the initiating subject. These levels together form the base and the supplementary part of the pension system.

Key words: universal pension system, pension system reform, multi-pillar pension systems

1 Katedra Zarządzania Ryzykiem i Ubezpieczeń, Uniwersytet Ekonomiczny w Krakowie, ul. Rakowicka 27, 31-510 Kraków; author's email address: tomasz.jedynak@uek.krakow.pl, ORCID — 0000-0003-4141-6654. 


\section{Introduction}

In the approach presented since the 1999 pension reform, the universal retirement system in Poland is consistently demonstrated as a three-pillar one (Bezpieczeństwo dzięki różnorodności [Security Through Diversity], 1997). In this concept, referring to the World Bank proposal (World Bank, 1994), the first pillar is the mandatory part of the system, administered by the public institution (the Social Insurance Institution, SII; Polish: ZUS), financed by the repartition method (pay-as-you-go, PAYG). Also compulsory, the second pillar is fully funded system, and the key role therein is played by the privately owned financial institutions (General Pension Societies, Polish: PTE). The third pillar, in turn, is a voluntary, yet state-promoted capital scheme in which various financial institutions offer pension products.

However, over the last decade and more, various modifications have been introduced to the universal pension system, which, directly or indirectly, caused a change in its architecture. Moreover, subsequent reforms are currently implemented, resulting in a further erosion of the three-pillar concept of a pension scheme. The modifications that explicitly influence the shape of the pension scheme include the changes in the functioning of the open pension funds and introducing the sub-accounts in the Social Insurance Institution, as well as implementing the employee capital pension schemes planned for 2019. The quotes from key politicians demonstrate that in the near future, we can also expect the open pension funds to be completely eliminated. Changes that result in the increasing number of persons to draw the minimal pension (lowering the retirement age and the length of service entitling to a minimal pension, introducing additional concessions in paying social security contributions for entrepreneurs) (Jajko-Siwek, 2017) have, in turn, an intermediate influence on the functioning and the shape of the pension scheme. The effect of these changes is the progressive switch from the key assumption of the 1999 reform, that is, linking the pension amount to the amount of the contributions paid, which causes more and more numerous calls for introducing the so-called civic pension (Gwiazdowski, 2012).

The observed evolution of the Polish pension scheme is therefore raising a question whether the three-pillar approach, presented since the 1999 reform, is still valid and accurately reflects the concept of how the universal pensions scheme operates in Poland. A potentially negative answer to that question, in turn, produces a dilemma on the means of presenting the shape of the pension scheme that would reflect its nature accurately. The above questions express the research problem tackled in this paper, and the main purposes of the work that aims at solving it are: 1) to review the pension scheme typologies, with particular attention to the multi-pillar concepts; 2) to include a brief presentation of the general pension scheme's evolution in the years 1999-2018; 3) to establish the key dilemmas stemming from the traditional three-pillar approach; 4) to attempt to formulate a new concept to present the architecture of the Polish pension scheme.

To achieve the particular objectives of this paper, research methods based on inductive reasoning have been used. In the first place, a theoretical and compiling analysis was 
performed on the basis of literature review. Then, criticism of selected concepts was attempted on the basis of the conclusions of these analyses, along with synthesising the compiled material and formulating own proposals on the new concept of presenting the shape of the Polish pension scheme.

\section{Pension scheme typology}

From a legal and formal point of view, the pension scheme (the pension protection system) are institutional solutions aimed at enabling the system participants with nonearned assets of subsistence for the old age by establishing the rules of 1) accumulating retirement savings, and 2) by making retirement benefit payments (Szumlicz, 2005). Thus understood, the pension scheme constitutes a factually clearly distinguished subsystem within a widely understood social security scheme. At the same time, the scope of the pension security scheme entails a specific type of social risk which is the risk of old age, and its main task is to enable a certain level of financial security in the period after ceding the professional activity (Szumlicz, 2004).

In economics, the pension scheme is generally defined by demonstrating two perspectives of its perception. In the macroeconomic approach, the pension scheme is defined as the tool of dividing the current GDP between the working and the retired generations. From an individual's point of view, in turn, the retirement system is treated as the tool of allocation income within the life cycle (Góra, 2003).

The primary objective of pension schemes' existence is to enable their participants with income after they cease their professional activity (Góra, 2003). More widely, it can be thus said that the objectives of the contemporary pension schemes is to equalise the level of consumption in the life cycle and to satisfy the vital needs of the elderly. The objectives presented to pension schemes also include helping the poor and income redistribution, as well as additional social and economic aims, such as, for example, stimulating the economic growth (Barr, Diamond, 2014).

Taking into account the rules for the organisation and functioning of the contemporary pension schemes, the state-of-the-art tends to classify them according to the various basic criteria (cf. Table 1).

The basic pension scheme classification criteria demonstrated in the table are subjects of in-depth analyses in the robust state-of-the-art (Góra, 2003; Żukowski, 2006; Chybalski, 2012). Thus, it is not my purpose to describe them here in detail. However, it must be observed that the designated criteria enable a synthetic characterisation of the rules for the functioning of the various pension schemes. They also enable a consistent presentation of the multi-pillar systems currently functioning in many countries, where multiple pension "subsystems" (plans) operate in parallel. ${ }^{2}$ A particular feature of these multi-pillar system is that within their framework, various combinations of funding schemes and benefit

2 Here, after Szumlicz (2004), it has to be stressed that the various muti-pillar typologies mainly aim at presenting the scheme, and not particular formal or legislative solutions. 
calculation, the type of managing entities and the coercion to participate are used. In the case of such schemes, the basic classification criteria in Table 1 enable the characteristics of their particular components, yet they do not allow for a comprehensive presentation of the complex nature of the entire multi-pillar scheme. For that reason, the state-of-the-art gives many suggestions as to the multi-pillar scheme typology.

Table 1. Selected pension scheme classification criteria

\begin{tabular}{|l|l|}
\hline \multicolumn{1}{|c|}{ Criterion } & \multicolumn{1}{c|}{ Pension scheme types } \\
\hline nature of benefit & $\begin{array}{l}\text { insurance schemes (Bismarck type) and basic pensions } \\
\text { (Beveridge type) }\end{array}$ \\
\hline creation method & repartition and capital schemes \\
\hline financing method & financial and non-financial systems \\
\hline benefit calculation method & $\begin{array}{l}\text { defined benefit (DB) and defined contribution (DC) } \\
\text { systems }\end{array}$ \\
\hline nature of managing entity & publicly and privately governed schemes \\
\hline coercion to participate & compulsory and voluntary schemes \\
\hline type of resource allocation & individual or group \\
\hline means of generating a rate of return & $\begin{array}{l}\text { real economy, financial markets, increasing the share } \\
\text { of GDP ending with the retired }\end{array}$ \\
\hline
\end{tabular}

Source: own work, based on Chybalski, 2012, pp. 28-31; Góra, 2003, pp. 129-135.

One of the first concepts of the multi-pillar system was the one proposed by Beveridge, of the three pillars of retirement security. It assumed that the first pillar was supposed to ensure a minimum pension, fully guaranteed by the state and funded by the supply method. The objective of the second pillar was to complement the minimum basic benefits with an insurance pension, depending on the salary and years in the workforce. The third pillar, in turn, was meant to be an entirely voluntary scheme based on the offer of private insurance institutions (Golinowska, 1993).

The three-pillar perspective, nowadays deemed traditional, underlines the substantial criterion of division. On the basis of defining the three entities with whose initiative the particular components of the pension scheme are associated (the state, the employer, the household), the three components, the pillars, are distinguished. Moreover, this perspective also applies the income criterion, which serves for establish which level of security (benefits) should be provided by the particular components (pillars) of the system (Szumlicz, 2004).

In the 1990s, a three-pillar concept was proposed on the basis of the experience of three countries: Switzerland, Chile and Singapore (hence its name, Swiss Chilanpore). According to that proposal, the first pillar was supposed to be based on the Swiss baseline 
scheme model, the second pillar-on the Chilean system of individual capital accounts governed by private entities, and the third pillar-on voluntary (individual or company) savings accumulated by the Singaporean model (Vittas, 1993; Wiktorow, 1996).

Currently, the most famous typologies of the multi-pillar schemes include: the three-pillar World Bank concept, the three-pillar Organisation for Economic Co-operation and Development (OECD) concept and the four-pillar International Labour Organisation (ILO) concept.

The three-pillar World Bank concept (World Bank, 1994) assumes that retirement benefits can be financed from taxes (contributions) or savings, and the particular components of the pension scheme may be administered by public or private institutions. Moreover, participation in the particular pillars can be mandatory or voluntary. On that basis, the World Bank recommended that the pension scheme be based on three pillars. The first pillar was supposed to be a mandatory part of the scheme, based on the publicly governed pay-as-you-go model. It was meant to be small in size and ensure a minimum level of benefits. The second pillar, also compulsory, was supposed to be governed via private institutions and be based on capital financing. That pillar was supposed to adopt the form of group Occupational Pension Schemes or individual savings. Just as the second pillar, also the third one could be formed from occupational or individual pension schemes. However, it was supposed to be entirely voluntary and aimed at increasing the level of future benefits.

The classic three-pillar scheme sustained a modification in 2005, when the World Bank made a proposal of a five-pillar pension scheme (Holzman, Hinz, 2005). The new concept was meant to take into account the different nature of various target groups participating in the pension scheme: the poor, the gray market and the formal sector. Taking the two first groups into account in particular, a non-contribution zero pillar guaranteeing a minimal benefit, directed to the general public and the 4th pillar including all forms of accumulating pension capital (both financial and non-financial) and the family's support within the natural system ${ }^{3}$ were added in this approach.

OECD (1998) proposed an alternative to the World Bank's classification of multipillar schemes. It assumes that the pension scheme is composed of three tiers that achieve different objectives of pension security. Tier 1 is meant to protect from the risk of poverty caused by the old age. It is created with a compulsory, non-financial pension scheme governed by the state. Tier 2 is meant to protect from the risk of retirement benefit inadequacy. It is composed both from financial and non-financial compulsory retirement plans with defined contributions or defined benefit. Tier 3 is composed of voluntary pension savings that enable raising the individual replacement rate.

In a slightly modified version, the OECD taxonomy, focusing on the aims of particular pillars, is also used in the European Union publications (Lannoo et al., 2014). The only difference between the two classifications tackles capital occupational plans. If such plans embrace less than $60 \%$ of the population, OECD classifies them as a part of level 3

\footnotetext{
3 At the same time, this has to be.
} 
(voluntary savings). Union publications, in turn, consider such plans a part of the second pillar, assuming that the third pillar is composed exclusively of fully voluntary plans (Lannoo et al., 2014, p. 17).

In the International Labour Organisation concept (Gillion, 1999), the pension scheme is composed of four tiers: 1) a universal or discretionary minimum universal pension, enabling protection against poverty (the so-called tier zero); 2) a compulsory pension scheme with defined benefit, publicly governed and financed from non-financial contributions (pay-as-you-go), enabling a fair replacement rate; 3 ) a generally compulsory, privately governed, individual or occupational financial pension plan with a defined contribution, enabling a raise of the replacement rate to the desired level; 4) a fully voluntary financial pension plan with a defined contribution, enabling individual income allocation in the life cycle.

The national state-of-the-art contains many references to the above mentioned pension scheme typologies. Żukowski (1997) determined three layers of pension protection: 1) a social (basal) pension security, public, compulsory and universal, constituting an element of social security; 2) an occupational or professional pension security organised by the employer for the benefit of the employees, voluntary or compulsory; 3 ) individually pension security or the security stemming from the citizens' foresight, generally voluntary. Similarly, with the initiating entity criterion, Handschke, Łyskawa and Ratajczak (2005) distinguished the baseline, occupational and individual retirement protection. While comparing the Polish pension scheme to the World Bank's five-pillar one, Chybalski (2012, p. 36), in turn, claimed that all pillars were present in Poland, while the zero pillar's role is played by social assistance and the minimum retirement pension guarantee, pillars one, two and three are the relevant universal pension schemes, and pillar four comprises all other forms of accumulating capital and the family's support.

As rightfully observed by F. Chybalski (2012), as well as M. Dybał (2013), although they differ in the assets of defining the particular levels (pillars), the presented concepts indicate the main direction of changes in the contemporary pension schemes, i.e. the diversification of the retired persons' sources of income. When referring to the presented multi-pillar pension scheme typologies, it is also worth noting that the OECD concept, which takes into account the type of risk it secures against as the classification criterion of the pension scheme levels, appears to be the most intuitive. However, it is also the least precise in the description of various pension schemes. The four-pillar ILO classification is more detailed, differing from the 1994 World Bank concept by detailing the part of the system aimed at protecting the poorest part of the society (Level 1). The modified five-pillar World Bank proposal seems to be the most complete, and therefore the most useful to describe the contemporary pension scheme, taking into account both the zero pillar and the informal pension products (pillar four), which gain importance in today's pension systems.

While at the typology of pension schemes, the ongoing discussion on terminological correctness should be mentioned. Since the World Bank proposal (1994), many authors 
use the term "pillar" to describe the particular components (elements) of the pension scheme. However, some researchers observe that this descriptor is not always fully adequate (Źukowski, 1997; Szumlicz, 2004). M. Żukowski supports this notion with the following arguments: 1) the scope of particular components of the retirement system is varied, thus, the "pillars" are strongly uneven, and 2) ties between particular pillars usually exist, causing them to overlap. This author also argues that the "pillar" terminology has an ideological hue, suggesting that each of the pillars is indispensable for the orderly functioning of the scheme. In this context, Żukowski proposes "layers" or "degrees" as more adequate descriptors of the particular pension scheme components.

\section{Evolution of the universal pension scheme, 1999-2018}

The construction of the new pension scheme in Poland began in the mid-1990s, when the bases of the structural reform ${ }^{4}$ of the entire social security scheme have been established (Bezpieczeństwo dzięki różnorodności... [Security through Diversity...], 1997). The reform entered into force in 1999, and with regards to the pension scheme, the move from the defined benefit system to a defined contribution one was, without a doubt, one of its key elements. Moreover, one of the important assumptions of the new system was to diversify the sources of pension payout, aimed at increasing the security of the entire scheme. Thanks to this, with regard to the World Bank guidelines of the day (World Bank, 1994), the architecture of the system was based on a three-pillar construction with capital elements, in which, nevertheless, the pillar differentiation criterion has been modified. Taking into consideration the specific nature of the transformed scheme, the creators of the reform proposed three pillars financed by the employee and the employer. ${ }^{5}$ The mandatory first pillar was supposed to be governed by the Social Insurance Institution and function on the basis of the pay-as-you-go system; the second one, also mandatory, was supposed to be based on a funded scheme, governed by privately managed Pension Funds Societies, the Open Pension Funds; the third pillar, in turn, was a voluntary mechanism of group savings accumulation, promoted by the state, but organised by the employers.

A visual representation of the shape of the new pension scheme introduced in 1999 is shown in Table 2. It references the representation of the reformed system's architecture in the works from the period of its implementation

4 In contrast to the parametric reforms, which mainly aim at ensuring a financial balance or income adequacy of the pension scheme, the structural reforms have a considerable impact on the change in the concepts and rules (paradigms) of the pension schemes' operation (Kalina-Prasznic, 2011).

5 Whereby many explanations exist for pension funds that are privately governed and financed from the mandatory contribution. For instance, Orenstein (2008) claims it was an effect of pressure from international financial institutions. According to Müller (2003), pivotal role was played by the pressure from the International Monetary Fund and the example of the Chilean report. 
Table 2. The shape of the universal pension scheme in Poland post-1999 reform

\begin{tabular}{|l|c|c|c|}
\hline & Pillar 1 & Pillar 2 & Pillar 3 \\
\hline Form & $\begin{array}{c}\text { The insured person's } \\
\text { account in the Social } \\
\text { Insurance Institution }\end{array}$ & Open Pension Funds & $\begin{array}{c}\text { Employee Pension } \\
\text { Programmes (EPP) }\end{array}$ \\
\hline $\begin{array}{l}\text { Governing } \\
\text { institution }\end{array}$ & $\begin{array}{c}\text { Social Insurance } \\
\text { Institution }\end{array}$ & $\begin{array}{c}\text { Pension Funds } \\
\text { Societies }\end{array}$ & $\begin{array}{c}\text { Financial market institutions } \\
\text { on the basis of an agreement } \\
\text { with employer }\end{array}$ \\
\hline $\begin{array}{l}\text { Nature of } \\
\text { participation }\end{array}$ & mandatory & mandatory & voluntary \\
\hline Contribution amount & $12.22 \%$ & $7.3 \%$ & limited amount \\
\hline $\begin{array}{l}\text { Financing and } \\
\text { benefit calculation }\end{array}$ & pay-as-you-go, NDC* & fully funded, DC** DC \\
\hline
\end{tabular}

* NDC-nonfinancial defined contribution, ** DC—defined contribution

Source: Jedynak, 2014.

However, in the years that followed the reform's implementation, a correction of certain solutions proposed in 1999 has proven necessary. In the first turn, particular attention had to be directed towards the third pillar, which, contrary to the expectations, has not stirred interest among the future retired persons (Rutecka, 2014; Kawalec, Błażuk, Kurek, 2015; Jedynak, 2016a). Privatisation of pensions within the second pillar and the functioning of the Open Pension Funds has also proven debatable (Orenstein, 2008; Góra, Oręziak, Żukowski, 2011). Other important issues included the principles of establishing the retirement age (Muszalski, 2009; Szczepański, 2016; Jedynak, 2016b), the rules for granting minimum pensions and pension privileges for selected occupational groups (Grodzicki, 2012; Walczak, 2017). In response to these problems, a series of actions have been taken in the years 1999-2017, to mention, among others:

1. Adopting the amended act on Employee Pension Programmes and introduction of Individual Pension Accounts (2004).

2. Changes in the functioning of the second pillar (2011) - the so-called small Open Pension Funds reform.

3. Raising and aligning the universal retirement ages for men and women (2012).

4. Changes in the scope of operation of the Open Pension Funds and transferring a part of OPF funds to the Social Insurance Institution (2014)—-the so-called large Open Pension Funds reform.

5. Return to the pre-2012 principles of establishing the retirement age (2017).

6. Introducing the Employee Capital Plans (2019).

In the context of changes to the pension scheme, it is also worth mentioning that, according to the information published by the Ministry of Development (2016) and public declarations of the government representatives, the final liquidation of the Open Pension Funds seems to have been decided. 
Not leaving room for detailed analysis on the course of particular stages of building the pension scheme, it is worth noting that the consecutive modifications have strongly influenced its shape, thus leading to progressive blurring of its initial shape (cf. Table 3).

Table 3. The shape of the universal pension scheme in Poland (2018)

\begin{tabular}{|c|c|c|c|c|c|c|}
\hline & \multicolumn{2}{|c|}{ Pillar 1} & "Pillar 2" & \multicolumn{3}{|c|}{ Pillar 3} \\
\hline Form & $\begin{array}{l}\text { the insured } \\
\text { person's account } \\
\text { in the Social } \\
\text { Insurance } \\
\text { Institution }\end{array}$ & $\begin{array}{l}\text { sub-account } \\
\text { in the Social } \\
\text { Insurance } \\
\text { Institution }\end{array}$ & $\begin{array}{l}\text { Open } \\
\text { Pension } \\
\text { Fund } \\
(\mathrm{OPF})\end{array}$ & $\begin{array}{l}\text { Employee } \\
\text { Pension } \\
\text { Programmes } \\
\text { (EPP) }\end{array}$ & $\begin{array}{l}\text { Individual } \\
\text { Pension } \\
\text { Account } \\
\text { (IPA) }\end{array}$ & $\begin{array}{l}\text { Individual } \\
\text { Pension } \\
\text { Security } \\
\text { Account } \\
\text { (IPSA) }\end{array}$ \\
\hline $\begin{array}{l}\text { Governing } \\
\text { institution }\end{array}$ & \multicolumn{2}{|c|}{ Social Insurance Institution } & $\begin{array}{l}\text { Pension } \\
\text { Funds } \\
\text { Societies }\end{array}$ & \multicolumn{3}{|c|}{ financial market institutions } \\
\hline $\begin{array}{l}\text { Nature of } \\
\text { participation }\end{array}$ & mandatory & mandatory & $\begin{array}{l}\text { possibility } \\
\text { to resign }\end{array}$ & \multicolumn{3}{|c|}{ voluntary } \\
\hline \multirow{4}{*}{$\begin{array}{l}\text { Contribution } \\
\text { amount }\end{array}$} & \multirow{4}{*}{$12.22 \%$} & \multicolumn{2}{|c|}{$7.30 \%$} & \multirow{4}{*}{\multicolumn{3}{|c|}{ limited amount }} \\
\hline & & $7.30 \%$ & $0.00 \%$ & & & \\
\hline & & \multicolumn{2}{|c|}{$\begin{array}{l}\text { or (per the insured } \\
\text { person's choice): }\end{array}$} & & & \\
\hline & & $4.38 \%$ & $2.92 \%$ & & & \\
\hline $\begin{array}{l}\text { Financing } \\
\text { and benefit } \\
\text { calculation }\end{array}$ & $\begin{array}{l}\text { pay-as-you-go, } \\
\text { NDC }\end{array}$ & $\begin{array}{l}\text { pay-as-you- } \\
\text { go, NDC }\end{array}$ & $\begin{array}{c}\text { fully } \\
\text { funded, } \\
\text { DC }\end{array}$ & fully & funded, D & \\
\hline
\end{tabular}

Source: own work.

Over the past 20 years, momentous changes occurred in the functioning of the second pillar. They led to a number of uncertainties so as to the status of the open pension funds, partly voluntary since 2014, and the means to classify the sub-account in the Social Insurance Institution and the pension paid from the Social Insurance Fund, also including the assets previously accumulated in the OPFs. According to the primary assumptions, the second pillar was described as a compulsory capital component of the pension scheme, formed by the competing OPFs governed by the private Universal Retirement Societies. They were supposed to invest the contributions passed to them $(7.30 \%$ of the basis of assessment) in various financial market instruments. As a result of the aforementioned small and large reforms of the Open Pension Funds, the above definition of the second pillar ceased to be valid. From a theoretical point of view, after the 2014 changes, the concept of the second pillar may be considered twofold:

1. From the perspective of a part of the pension insurance contribution attributable to the original second pillar. In this perspective, the second pillar is formed by a sub- 
account in the Social Insurance Institution, to which, according to the insured person's decision, $7.30 \%$ or $4.38 \%$ of the basis of assessment for the contribution is transferred, and the Open Pension Funds, to which 2.92\% of the basis of assessment for the contribution can be transferred. This perspective generally overlaps with the way of presenting the shape of the pension scheme, conveyed at the occasion of the 2014 reform, and most of the later publications describing the shape of the pension scheme (the Ministry of Labour and Social Policy, 2013).

2. From the perspective of the principles of financing the future retirement benefits. According to this approach, the second pillar is constituted exclusively by the Open Pension Fund scheme, in which the capital method is used. The Social Insurance Institution sub-account, as a part of the pay-as-you-go scheme, should then be classified as a part of the first pillar. ${ }^{6}$ Such an understanding of the second pillar also overlaps with the substantial understanding, according to which the institution responsible for the operation of the first pillar is the Social Insurance Institution, whereas the construction of the second pillar is based on the publicly supervised private financial institutions (the OPF).

In respect to these suggestions, in my view, the post-2014 second pillar should be treated in accordance to the second of the presented viewpoints. Contrary to the first option, this approach thus reflects the fundamental differences in the functioning of the first and second pillars and guarantees a relative transparency of the make-up of the entire scheme. Taking into account the widely announced and presumably already agreed OPFs liquidation, the above remarks on defining the second pillar will probably become obsolete. The question will remain, however, how to re-define the second pillar of the Polish pension scheme after the OPF liquidation. Very slight differences between the account and the sub-account in the SII, coming down to different valorisation rules and the limited possibility to inherit funds are, in my opinion, not strong enough an argument to highlight two separate pillars within the public "SII" scheme.

Initially, enriching the third pillar with two form to accumulate savings (first the IPA [Polish: IKE], then the IPSA [Polish: IKZE]) only led to a slight redefinition of this part of the scheme: the initial concept of an additional pension savings accumulation scheme, initiated by the employer, has been replaced with a wider concept of an additional pension scheme (Jedynak, 2016a). The issue of the third pillar definition has been, nevertheless, complicated by the introduction of the Employee Capital Plans (ECP, Polish: PPK) from January 2019.

From a formal point of view, the ECP are a legally regulated and state-supported mechanism of group accumulation of long-term savings for pension purposes, functioning within the capital part of the pension scheme. At first glance then, the ECP are a form of pension savings accumulation, close to the OPS, thus, they should naturally be treated as another instrument comprised within the third pillar. It is also the way the ECP are

6 It is worth noting that the authors of the OPF reform have demonstrated that the argument for considering the sub-account in the SII as a part of the fully funded system is allowing for a partial inheritance of the funds evidenced therein. 
presented in the government documents (Ministry of Finance, 2018b) and the press and promotional releases based on them. However, taking into consideration the specific features of the ECPs, it appears that in relation to the initial shape of the 1999 pension scheme, they should be positioned somewhere at the boundary between the second and the third pillar (Balcerowski and Prusik, 2018).

On one hand, similarly to the Open Pension Funds, the ECPs are, after all, directed at the entire working population, and the legislator imposes an obligation to create them on all employees and assumes universal participation. Moreover, the ECPs foresee the capital method of financing the benefits, based on the obligation to pay at least the minimum contribution calculated as a percentage of the remuneration and are governed by private financial institutions. On the other hand, the ECPs also leave a margin of freedom within the shape of the contribution, allow the so-called auto-enrolment and auto-re-enrolment with an opt-out option and foresee tax incentives aiming at encouraging the public to accumulate pension savings. In this context, Balcerowski and Prusik (2018) claim that the formal participation in the ECP system is mandatory in nature, whereas only the so-called material participation (continuous contribution payment) is voluntary.

A more discreet changes, yet no less important in the consequences, are brought by a considerable growth in the number of the assigned minimum pensions (Jajko-Siwek, 2017). On one hand, this phenomenon stems from a drastic decline of the replacement rate, one of the consequences of the move to the defined contribution scheme (Góra and Rutecka, 2013; European Comission, 2015; OECD, 2015). On the other hand, it is reinforced by the moves such as lowering the retirement age and diminishing the number of years of work required to obtain the minimal pension, or exempting business owners from the obligation to pay parts of the contributions (see the so-called 2018 Konstytucja Biznesu [Business Constitution]). In the context of the growing number of minimum pensions assigned, the announcement of granting these benefits to the selected social groups, even without meting the years of work criterion (e.g. the proposal, recently formulated by the government, to grant minimum pension to mothers that raised at least four children) are also important.

The forecast growth of the number of persons receiving the minimal benefit causes the suggestions to introduce the so-called civic retirement benefit, a benefit paid to all citizens in the identical amount, regardless of the number of years worked and the amount of contributions paid, to appear (BCC, 2010; Gwiazdowski, 2012). The argument raised by the partisans of this solution is based on the claim that since in the future, most of the retirement pensions will nevertheless be the minimum benefits subsidised by the state, then the complex contribution system can be replaced with a less expensive and simpler solution. Not entering here into a discussion on the rationale and validity of introducing civic retirement pensions, due to the aforementioned tendencies, it has to be noted that this concept is entering the Polish pension system "by the back-door". Basing on the sited retirement pension prognoses, one should expect that the Social Insurance Institution benefits (today's first and second pillars) will continue to lower, thus leading to the rising number of the granted minimum pensions which, in the future, will start playing the role 
of the particular quasi-civic pension. A similar situation, after all, is already in place in the strongly budget-subsidised (over $90 \%$ of the income) agricultural system, in which the distribution of the values of the benefits paid is strongly concentrated around the average, amounting to PLN 1094 (KRUS, 2018).

Taking the shape of the universal pension scheme in Poland into account, it must nevertheless be noted here that the concept of civic pension does not inscribe into the traditional three-pillar concept in any way. The civic retirement pension in its clear shape, nor in the form of a benefit paid from the Social Insurance Institution contribution system, low and relatively equal for all, does not fit into it either. This solution can be more likely inscribed in the concept of tier 1 in the OECD classification (protection against the risk of poverty), the zero tier according to the ILO (a minimum retirement pension enabling protection against poverty), or, to a lesser extent, in the zero pillar in the World Bank 2005 classification. Moving beyond other challenges and problems relating to the introduction (official or "back-door") of a solution of this type in Poland, it must be noted that it will require a thorough redefinition of the concept of presenting the entire pension system.

\section{A new concept of presenting the Polish pension scheme}

The already formulated remarks on the shape of the universal pension scheme in Poland call to pose a question already signalled in the introduction, on the new model of presenting this shape. Adopting the most basic approach, a proposal can be made similar to those by Góra and Rutecka (2013), separating a basal and additional part of the pension scheme. ${ }^{7}$ Adopting the Polish conditions, the basal part covers the entire "Social Insurance Institution" part of the scheme, where the mandatory retirement pension insurance contribution goes. It is thus created by the first and second pillar to date, including the OPFs (regardless of their future fate). The additional part is, on the other hand, formed by all the savings accumulated in the instruments of the third pillar to date (Individual Pension Account, Individual Pension Security Account, Employee Pension Programmes) and the savings accumulated for pension purposes outside the state-supported forms. Starting January 2019, the Employee Capital Plans also constitute a solution that is an integral element of the additional part of the scheme. An advantage of this approach is its simplicity and the unambiguous classification criterion (the mandatory participation). This division may, and even should thus be promoted within the educational policy aiming at reinforcing the citizens' pension awareness and stimulating the growth of individual pension savings.

However, it must be observed that this simple classification does not reflect the diversity of the particular pension system components and may thus have limited applicability to more advanced analyses, including the academic ones. Therefore, I would proposed that within this new concept of presenting the Polish pension system, the division between the basal and additional part be completed with the criterion of the entity initiating the

\footnotetext{
7 A similar division is presented by Golinowska (1993) and Szumlicz (1997).
} 
particular components of the scheme. This criterion references the traditional three-pillar approach and the concept of the three layers of pension security by Żukowski (1997). It must be strongly underlined that the proposed criterion is based on initiating and not financing the particular components of the scheme. It stems from the fact that the solutions such as co-financing the mandatory contributions to pension insurance from the employee and the employer, covering the EPP and ECP contributions by the employee and the employers with the ongoing incentives in the form of direct subsidies financed by the state budget, as well as subsidies to the minimum pensions financed by the state budget make it basically impossible to identify separate parts of the Polish system financed by the state, the employer and the employee. In addition, it also appears that a complex look at the pension system also requires the growing importance of the informal forms of retirement plans to be included.

Taking the above remarks into consideration, I stipulate that four "layers" of the pension system be identified within the new concept of presenting the Polish pension system (cf. Table 4).

Table 4. The stipulated way to present the shape of the Polish pension scheme

\begin{tabular}{|c|c|c|c|c|c|}
\hline & \multicolumn{2}{|c|}{ BASAL PART } & \multicolumn{3}{|c|}{ ADDITIONAL PART } \\
\hline & Layer 1 & Layer $1 a^{a}$ & Layer 2 & Layer 3 & Layer 4 \\
\hline Form & $\begin{array}{l}\text { SII (account and } \\
\text { sub-account) }\end{array}$ & OPF & EPP, ECP & IPA, IPSA & $\begin{array}{l}\text { other } \\
\text { investments, } \\
\text { natural system }\end{array}$ \\
\hline $\begin{array}{l}\text { Administration } \\
\text { /governing }\end{array}$ & public & private & private & private & private \\
\hline $\begin{array}{l}\text { Initiating } \\
\text { entity }\end{array}$ & \multicolumn{2}{|c|}{ the State } & employerc & $\begin{array}{c}\text { employee/ } \\
\text { saving person }\end{array}$ & $\begin{array}{l}\text { employee/ } \\
\text { saving person }\end{array}$ \\
\hline $\begin{array}{l}\text { Nature of } \\
\text { participation }\end{array}$ & mandatory & $\begin{array}{l}\text { opt-out } \\
\text { option }\end{array}$ & quasi-mandatory & voluntary & voluntary \\
\hline $\begin{array}{l}\text { Contribution } \\
\text { amount }\end{array}$ & \multicolumn{2}{|c|}{$19.52 \%$} & $\begin{array}{l}\text { discretionary } \\
\text { (with maximum/ } \\
\text { minimum) }\end{array}$ & $\begin{array}{l}\text { discretionary } \\
\text { (with } \\
\text { maximum) }\end{array}$ & discretionary \\
\hline $\begin{array}{l}\text { Allocation of } \\
\text { funds }\end{array}$ & \multicolumn{2}{|l|}{ group } & group & individual & individual \\
\hline $\begin{array}{l}\text { Benefit } \\
\text { financing }\end{array}$ & $\begin{array}{l}\text { pay-as-you-go, } \\
\text { NDC } \\
\text { State subsidies }\end{array}$ & $\begin{array}{l}\text { fully } \\
\text { funded, } \\
\text { DC }\end{array}$ & fully funded, DC & $\begin{array}{l}\text { fully funded, } \\
\text { DC }\end{array}$ & $\begin{array}{l}\text { fully funded } \\
\text { or informal }\end{array}$ \\
\hline
\end{tabular}

a The transitional form; ${ }^{b}$ pertains to the subsidies to the minimal pensions; ${ }^{\mathrm{c}}$ with State support (incentives).

Source: own work. 
In the terminological aspect, the stipulated proposal references the conclusions of the discussion on naming the particular components of pension security (see the section entitled Pension scheme typology). It should be especially stressed that the particular "layers" are not equal and may be interlinked, which results in them "permeating" (Z̈ukowski, 1997). The necessity to differentiate the new proposal from the concept of "pillars", already established in Poland, also works in favour of the term "layers".

In the stipulated proposal, Layer 1 is identical to its basal part. It covers the part of the system stipulated by the State and financed within the mandatory contribution to the pension insurance, i.e. the account and the sub-account in the SII. The OPFs also operate within Layer $1^{8}$, whereas to underline the capital financing and administration by private institutions, they could operate as Layer 1a. Retirement benefits paid out within Level 1 are the baseline retirement pensions, which, by assumption, ensure relatively low substitution levels, protecting the system members from poverty, yet not enabling optimal income allocation within the life cycle. The pension scheme participants should thus also make use of its additional part, consisting of layers 2, 3 and 4 .

Layer 2 consists of the two programmes initiated by employers for the employees' benefit: the already existing, yet unpopular EPPs and the implemented, yet presumably much more universal thanks to the auto-enrolment mechanism: the ECPs. Both programmes are forms of group saving for retirement, state-promoted via an extensive incentive scheme, within which the assets are governed by private financial institutions. As previously mentioned, the contributions to the EPPs and the ECPs are financed from the employer and employee's assets in different parts. The pay-out of funds from Layer 2, as a rule, should have a form of an annuity, or possibly, a programme pay-out. ${ }^{9}$

Layers 3 and 4 are composed of fully voluntary forms of individual retirement plans, financed with the own assets of the future retired persons. Members of all sociooccupational groups (employees, entrepreneurs, farmers, uniformed services, etc.), as well as non-employed persons may participate in Levels 3 and 4. The difference between Layers 3 and 4 generally comes down to the scope of the State interference, as well as to the means of accumulating the savings. Within Layer3, there are instruments of accumulating voluntary savings (the IPAs and IPSAs) that are formalised (e.g. within the pay-out possibilities) and State-promoted with tax incentives. Layer 4, in turn, is formed with all, including non-financial and non-formalised forms of individual retirement plans.

The stipulated concept did not include a zero layer corresponding to the zero pillar in the World Bank proposal and tier 1 from the ILO classification. To my mind, it should be equated only with a classical civic pension (minimal benefit), fully sponsored with the

8 It is presumably only temporary, up to the time of their stipulated liquidation.

9 It should be stated here that the draft act on the ECP foresees a programme pay-out of 120 monthly instalments (10 years) as a basic pay-out form. In the context of an instrument to accumulate additional retirement savings, such solution must be assessed negatively. See a wider presentation of the topic in Jedynak (2018). 
State budget assets. In the meantime, the minimum pensions in Poland are linked to the obligations of earlier contribution payment and the minimal years of work requirement. They are also, as a rule, sponsored within the insurance system, and not the provision system. Therefore, even when faced with the drastically increasing number of the minimum pensions paid out, I do not currently find the justification to treat such benefits different from any other pensions paid out from the Social Insurance Institution, the difference being them partially sponsored with the State budget.

\section{Conclusion}

The referred phenomena and tendencies on the evolution of the Polish pension system lead to a conclusion that the existing way of presenting its shape has become obsolete. Basing on the reflections herein, it can be concluded with all certainty that the classic three-pillar concept has already ceased to adequately reflect the factual state of the system. Moreover, the already implemented (ECPs), planned (OPFs) and "back-door" (civic pension) changes in the pension scheme cause that in the very near future, in no way will this concept reflect its factual shape. Therefore, a justified need emerges to drastically redefine a concept of presenting the Polish pension system.

The proposed new concept of presenting the universal pension scheme in Poland stipulates distinguishing four layers of the old-age security. Layer 1 is identical to the basal part of the system. It is the mandatory part of the scheme, publicly governed (the SII), financed in the PAYG system. Ultimately, this layer will be composed of the account and sub-account in the Social Insurance Institution. The additional part of the system is formed with layers 2, 3, and 4. Layer 2 are fully funded programmes organised by the employers on a quasi-mandatory basis (ECPs and EPPs), Layer 3-the State-supported individual forms of pension saving (IPA, IPSA), while Layer 4 are all other form of accumulating pension capital.

An undoubted advantage of the stipulated proposal is its legibility and transparency, even to an audience without thorough knowledge of the pension scheme theories (a clear initiating entity criterion). Also importantly, within its framework, there is a possibility to underline one of the key challenges in the Polish pension scheme: the problem of benefit adequacy. The proposed concept clearly demonstrates what is the basal and the additional part of the scheme and who is responsible for the amount of benefits from particular levels. An appropriately directed educational policy, making the future retired aware of the prospective Layer 1 benefits amount should thus strongly stimulate participation in the various additional forms of saving. In addition, in case of possibly introducing a guaranteed minimal benefit (the civic pension), the proposed way of presenting the shape of the pension scheme can easily be completed with adding a zero level. 
References

Balcerowski, M., Prusik, A. (2018). Wybrane aspekty prawne Pracowniczych Planów Kapitatowych. Warszawa: Instytut Emerytalny. Available at: http:/www.instytutemerytalny.pl/ wp-content/uploads/2018/03/Wybrane-aspekty-prawne-PPK-15-marca-2018.pdf [access date: 15.05.2018].

Barr, N., Diamond, P. (2014). Reformy systemu emerytalnego. Krótki przewodnik. Warszawa: Polskie Towarzystwo Ekonomiczne.

BCC (2010). Stanowisko BCC dotyczace pomystu na emerytury wicepremiera Pawlaka. Warszawa: Business Centre Club. Available at: https://www.bcc.org.pl/uploads/ media/2010-04-23_BCC_Pawlak_emerytury.pdf [access date: 10.05.2018].

Bezpieczeństwo dzięki różnorodności. Reforma systemu emerytalno-rentowego $w$ Polsce (1997). Warszawa: Biuro Pełnomocnika Rządu ds. Reformy Zabezpieczenia Społecznego.

Chybalski, F. (2013). Skuteczność $i$ efektywność systemu emerytalnego. Koncepcja analizy i próba pomiaru. Zeszyty Naukowe No. 1111, Rozprawy Naukowe, iss. 419. Łódź: Wydawnictwo Politechniki Łódzkiej.

Dybał, M. (2013). Reformy systemów emerytalnych. Zarządzanie i Finanse, Vol. 2, Issue 5, pp. 289-303.

European Commission (2015). The 2015 Ageing Report. Economic and budgetary projections for the 28 EU Member States (2013-2060). European Economy, no. 3. Available at: http://ec.europa.eu/economy_finance/publications/european_economy/2015/pdf/ ee3_en.pdf [access date: 31.05.2018].

Gillion, C. (1999). The ILO and Pensions. Geneva: International Labour Organization, Social Security Department.

Golinowska, S. (1993). Ewolucja i kierunki reform bazowych systemów emerytalno-rentowych na świecie. In: S. Golinowska (ed.), Bazowe systemy emerytalno-rentowe na świecie, vol. 1. Studia i Materiały, iss. 16. Warszawa: Instytut Pracy i Spraw Socjalnych.

Góra, M. (2003). System emerytalny. Warszawa: Polskie Wydawnictwo Ekonomiczne.

Góra, M., Oręziak, L., Żukowski, M. (2011). Dyskusja na temat zmian w systemie emerytalnym. Analizy $B A S$, iss. 2 (46) (special issue), pp. 1-11.

Góra, M., Rutecka, J. (2013). Elastyczny system emerytalny a obecne i przyszłe potrzeby jego uczestników. Ekonomista, no. 6, pp. 735-753.

Grodzicki, M. (2012). Emerytury branżowe w Polsce w kontekście teorii grup interesu. Studia Ekonomiczne, iss. 3 (LXXiV), pp. 345-370.

Gwiazdowski, R. (2012). Emerytalna katastrofa i jak się chronić przed jej skutkami. Warszawa: Zysk.

Handschke, J., Łyskawa, K., Ratajczak, J. (2005). Ryzyko emerytalne w systemie zabezpieczenia na starość. In: T. Szumlicz (ed.), Społeczne aspekty ubezpieczenia . (141-152). Warszawa: Oficyna Wydawnicza Szkoły Głównej Handlowej.

Holzmann, R., Hinz, R. (2005). Old-age income support in the 21st century. An international perspective on pension systems and reform. Washington, DC: World Bank. 
Jajko-Siwek, A. (2017). Quo vadis pensione? Perspektywy zmian w poziomie świadczeń emerytalnych w Polsce. Problemy Polityki Spotecznej. Studia i Dyskusje, iss. 38 (3), pp. 105-115.

Jedynak, T. (2014). Charakterystyka systemu emerytalnego w ramach powszechnego ubezpieczenia społecznego. In: W. Sułkowska (ed.), System ubezpieczeń społecznych. (67-73). Kraków: Wydawnictwo Uniwersytetu Ekonomicznego w Krakowie.

Jedynak, T. (2016a). The directions of the development of supplementary pension scheme in Poland. Journal of Insurance, Financial Markets and Consumer Protection, no. 22 (3), pp. $34-48$.

Jedynak, T. (2016b). Przesłanki kształtowania wysokości minimalnego wieku emerytalnego. Zeszyty Naukowe Uniwersytetu Ekonomicznego w Krakowie, no. 10 (958), pp. 33-49. DOI: 10.15678/ZNUEK.2016.0958.1003.

Jedynak, T. (2018). Wpływ wprowadzenia pracowniczych planów kapitałowych na adekwatność dochodową polskiego systemu emerytalnego. Ubezpieczenia Społeczne. Teoria i praktyka, no. 2 (137), pp. 33-56.

Kalina-Prasznic, U. (2011). Systemy emerytalne w warunkach kryzysów-między państwem a rynkiem. In: J. Kundera (ed.), Globalizacja, europejska integracja a kryzys gospodarczy. (693-704). Wrocław: Prace Naukowe Wydziału Prawa, Administracji i Ekonomii Uniwersytetu Wrocławskiego. E-Monografie, iss. 9.

Kawalec, S., Błażuk, K., Kurek, M. (2015). Jak mobilizować dodatkowe oszczędności emerytalne? Warszawa: Capital Strategy.

KRUS (2018). Kwartalna informacja statystyczna. III kwartat 2017 r. Warszawa: Kasa Rolniczego Ubezpieczenia Społecznego. Available at: https://www.krus.gov.pl/fileadmin/moje_dokumenty/dokumenty/statystyki-BE/KIS/2017/KWARTALNA_INFORMACJA_STATYSTYCZNA_-_III_kwartal_2017_r..pdf [access date: 28.05.2018].

Lannoo K., Barslund M., Chmelar A., von Werder M. (2014). Pension Schemes. Brussels: European Union. Directorate General For Internal Policies. Available at: http://www. europarl.europa.eu/RegData/etudes/STUD/2014/536281/IPOL_STU(2014)536281_ EN.pdf [access date: 31.05.2018].

Ministry of Development (2016). Plan na rzecz Odpowiedzialnego Rozwoju. Available at: https://www.mr.gov.pl/media/14840/Plan_na_rzecz_Odpowiedzialnego_Rozwoju_prezentacja.pdf [access date: 11.05.2018].

Ministry of Finance (2018a). Projekt ustawy o pracowniczych planach kapitałowych z 24.05.2018 r. Available at: http://legislacja.rcl.gov.pl/docs//2/12308305/12491764/12 491765/dokument343036.pdf [access date: 02.06.2018].

Ministry of Finance (2018b). Uzasadnienie do projektu ustawy o pracowniczych planach kapitałowych z 24.05.2018 r. Available at: http://legislacja.rcl.gov.pl/docs//2/12308305/ 12491764/12491765/dokument343038.pdf [access date: 28.04.2018].

Ministry of Labour and Social Policy (2013). Justification to the draft act on changes of certain acts in connection with the definition of pension payments from the Open Pension Funds regulations. Available at: https://www.mpips.gov.pl [access date: 16.05.2018]. 
Muszalski, W. (2009). Przemiany wieku emerytalnego. Polityka Społeczna, no. 3 (420), pp. 7-11.

OECD (1998). Maintaining Prosperity in an Ageing Society. Paris: Organisation for Economic Co-operation and Development.

OECD (2015). Pensions at a Glance 2015: OECD and G20 indicators. Paris: OECD Publishing. Available at: http://dx.doi.org/10.1787/pension_glance-2015-en [access date: 20.05.2018].

Orenstein, M. (2008). Privatizating Pensions: the Transnational Campaign for Social Security Reform. Princeton: Princeton University Press.

Rutecka, J. (ed.) (2014). Dodatkowy system emerytalny w Polsce—diagnoza i rekomendacje zmian. Warszawa: Towarzystwo Ekonomistów Polskich.

Szczepański, M. (2016). Analiza i ocena proponowanych zmian ustawowego wieku emerytalnego w Polsce. Finanse, Rynki Finansowe, Ubezpieczenia, iss. 1 (79), pp. 739-751.

Szumlicz, T. (2004). Zabezpieczenie emerytalne w systemach zabezpieczenia społecznego. In: T. Szumlicz, M. Żukowski (ed.), Systemy emerytalne w krajach Unii Europejskiej. (9-27). Warszawa: Twigger.

Szumlicz, T. (2005). Ubezpieczenie spoteczne. Teoria dla praktyki. Bydgoszcz-Warszawa: Oficyna Wydawnicza Branta.

Vittas, D. (1993). Swiss Chilanpore: The Way Forward for Pension Reform? In: The Implications for Social Adjustment Policies. International Social Security, Studies and Research, no. 34.

Walczak, D. (2017). Przywileje emerytalne — aspekt społeczno-ekonomiczny. Studia Oeconomica Posnaniensia, vol. 5, nr 10, pp. 49-62. DOI: 10.18559/SOEP.2017.10.4.

Wiktorow, A. (1996). System emerytalno-rentowy. Przestanki i możliwości reformowania. Gdańsk: Instytut Badań nad Gospodarką Rynkową.

World Bank (1994). Averting the Old Age Crisis: Policies to Protect the Old and Promote Growth. The World Bank Policy Research Report. Washington, DC: Oxford University Press.

Żukowski, M. (1997). Wielostopniowe systemy zabezpieczenia emerytalnego $w$ Unii Europejskiej i w Polsce. Między państwem a rynkiem. Poznań: Wydawnictwo Akademii Ekonomicznej w Poznaniu.

Żukowski, M. (2006). Reformy emerytalne w Europie. Poznań: Wydawnictwo Akademii Ekonomicznej w Poznaniu. 


\section{Ksztatt powszechnego systemu emerytalnego w Polsce $w$ świetle klasycznych typologii wielofilarowych}

Streszczenie

W ostatnich latach jest wprowadzanych i dyskutowanych szereg modyfikacji, które mają istotny wpływ na kształt powszechnego systemu emerytalnego w Polsce (m.in. reforma OFE, wdrożenie PPK, wprowadzenie emerytur obywatelskich itp.). Zmiany te powodują, że tradycyjny, trzyfilarowy sposób prezentacji kształtu tego systemu nie oddaje trafnie jego istoty. W opracowaniu, opierając się na proponowanych w piśmiennictwie typologiach wielofilarowych systemów emerytalnych, proponuje się nową koncepcję prezentacji kształtu powszechnego systemu emerytalnego w Polsce. Składają się na nią cztery, wyodrębnione przy użyciu kryterium podmiotu- inicjującego, poziomy zabezpieczenia emerytalnego, które tworzą razem część bazową oraz dodatkową systemu emerytalnego.

Słowa kluczowe: powszechny system emerytalny, reforma systemu emerytalnego, wielofilarowe systemy emerytalne 